\title{
Growth and Trend of Energy Consumption and Production in India
}

\author{
Itishree Pradhan \\ M.Phil Scholar, Dept. of Economics, Ravenshaw University, Cuttack-753003, Odisha, India \\ Manoj Kumar Das* \\ Assistant Professor, Ravenshaw University, Cuttack, Odisha, India-753003
}

\begin{abstract}
Energy has become one of the key elements in the era of globalization driven economic growth. On one hand, growth of an economy, with its global competitiveness, hinges on the availability of cost-effective and environmentally benign energy sources, and on the other hand, the level of economic development has been observed to be reliant on the energy demand. Therefore, this paper explores the sources of energy production in India and analyses the growth and trend in energy production and consumption. Nonparametric techniques like Mann-Kendal and Sen's slope technique has been used to analyse the trends. The study observes that though there is a sharp increasing trend of energy consumption in India, the production trend has been very dubious.
\end{abstract}

Keywords: Energy Production, Trends, Growth Rate

DOI: $10.7176 / \mathrm{JETP} / 10-1-01$

Publication date: January $31^{\text {st }} 2020$

\section{Introduction:-}

Energy has become one of the key elements in the era of globalization driven economic growth. To achieve targeted economic growth rates it is very necessary to increase consumption levels among diverse sectors. There is a strong two-way relationship between economic development and energy consumption. On one hand, growth of an economy, with its global competitiveness, hinges on the availability of cost-effective and environmentally benign energy sources, and on the other hand, the level of economic development has been observed to be reliant on the energy demand. In an effort to meet the demands of a developing nation, the Indian energy sector has witnessed a rapid growth. Areas like the resource exploration and exploitation, capacity additions, and energy sector reforms have been revolutionized. However, resource augmentation and growth in energy supply have failed to meet the ever increasing demands exerted by the multiplying population, rapid urbanization and progressing economy. Hence, serious energy shortages continue to plague India, forcing it to rely heavily on imports.

Comprehending that the dependence on energy is expected to increase further to achieve the targeted GDP growth rate of $8 \%$ during the Tenth Five-year Plan, the Government of India has granted high priority to the energy sector. The Government of India in the mid-term review of the Tenth Plan recognized the fact that underperformance of the energy sector can be a major constraint in delivering a growth rate of 8\% GDP during the plan period. It has, therefore, called for acceleration of the reforms process and adoption of an integrated energy policy. The extent of the increase in energy requirement over the Twelfth Five Year Plan depends on the elasticity of energy demand with respect to GDP, which has been falling over time and is currently around 0.80. Allowing for some further decline in the elasticity, a GDP growth rate of 9.0 per cent per year over the Twelfth Plan will require energy supply to grow at around 6.5 per cent per year. The ability to meet this energy demand depends on our ability to expand domestic production in critical energy sub sectors, notably petroleum, gas and coal, and meeting the balance requirement through imports. The total energy requirement (in terms of million tonnes of oil equivalent) is projected to grow at 6.5 per cent per year between 2010-11 and 2016-17. This is based on the assumption that the energy elasticity will decline over time. It is worth noting that import dependence on oil is expected to increase from 76.0 per cent in 2010-11 to 80.0 per cent by the end of the Twelfth Plan. Import dependence on natural gas is projected to increase from 19.0 per cent in 2010-11 to 28.4 per cent in 2016-17. In the case of coal, it will increase from 19.8 per cent in 2010-11 to about 22.1 per cent in 2016-17 (Planning Commission).

One of the key aspects in this backdrop, for growth is energy. Uninterrupted and quality supply of energy that can satisfy the needs of agricultural, manufacturing and service sectors- the three pillars of economy- can only ensure achieving of growth rates. However, severe shortage of energy appears to be creating pitfalls in reaching institutionalized growth rates. The relationship between use of energy and economic growth has been a subject of greater inquiry as energy is considered to be one of the important driving forces of economic growth in all economies (Pokharel, 2006). In recent years, most of the non-oil producing economies are facing energy deficiencies, as the oil producing economies are unable to meet up the world demand for oil. The supply constraint of energy could be attributed to the frequent geo-political tensions between the nations or natural physical supply constraints in the oil extracting regions. The increasing world demand for oil leads to frequent escalation in the world oil prices. Like shortage of oil, there exists shortage of electricity and other forms of energies viz. natural 
gas. The shortage can significantly affect the consumption and production in the economy. One or the other forms of energy becomes vital to all the sectors of the economy viz. agriculture, industry and services. This energy dependence being common to every sector of the economy 250 justifies the association between energy utilization and the overall economic growth rate in an economy. Hence, any deficiency in supply of oil, natural gas and electricity generations can directly constrain the economic activities, thereby inhibiting the growth rate. The declining supply of these sources of energy not only raises the input prices but also influences the prices of other commodities leading to a rise in overall inflation rate and thereby dampening the aggregate demand and growth rate.

Energy services matters more than ever in the global fight against poverty, because these services underpin economic growth that provides jobs in developing countries where they are sorely needed. Most economic activity would be impossible without energy, even the small scale village and household enterprises in developing countries that are the main source of income for the poor in those countries. The services that hydrocarbons and electricity provide - motive power for industry and agriculture; transportation of people and goods; heating and cooling of workplaces, power for appliances - increase productivity and economic output. Thus economic growth that creates jobs and raises incomes depends on greater access and more efficient use of energy services and their constituent energy resources (World Bank).

Urbanization and population intensify and thus posing a big challenge to economists and policy makers to deal with various issues. Energy is largely used in most populated areas. The densely-populated areas bring more economic activities such as transportation and business activities. However, higher population density can trigger environmental problems such as pollution. A crowded metropolitan area, traffic congestion, and great industrial activities can harm the environment and cause public health problems.

Population is inextricably connected with energy consumption. Limited and exhausted resources cause all countries to struggle for the great economic growth. Every year, the world population increase and the energy resources are increasingly needed in numerous human's activities. However, the limited resources of energy can limit the economic activities and thus hindering the economic development. People consume energy for various activities such as transportation, agriculture, and industries. We are unable to imagine that if exhausted energy occurs in the world; it can certainly cripple all countries economy. Lower population can probably reduce the demand in energy but a reduction in energy consumption can affect the economic growth. Therefore energy consumption is a strong determinant of economic growth. This study is to examine the relationship among population, energy consumption and economic growth.

\section{Sources of energy- consumption and production in India}

India is both a major energy producer and consumer. India currently ranks as the world's eleventh greatest energy producer accounting for about $2.4 \%$ of the world's total annual energy production and as the world's sixth greatest energy consumer, accounting for about $3.3 \%$ of the world's total annual energy consumption. Despite its large annual energy production, India is a net energy importer, mostly due to the large imbalance between oil Production and consumption. (GOI, 2006).With 15\% of the world's population and an economic growth rate that increases the aspiration of its people to better quality of life, India has a voracious appetite for energy. But the country lacks sufficient domestic energy resources, particularly of petroleum and natural gas, and must import much of its growing requirements. Currently, about $35 \%$ of India's commercial energy needs are imported. The Government of India's (GoI) Planning Commission predicts dramatic demand increases for coal and oil over the next 20 years. India's long-range plans, however, foresee coal as the sector with the most growth potential, fueled mostly by demand for power generation (India Energy handbook 2011). In this study the sources of energy includes coal, lignite, crude oil, natural gas and electricity. A historical summary of total consumption and production of primary conventional energy has described below during the period of 1970-71 to 2013-14.

\subsection{Coal and lignite}

India now ranks third amongst the coal producing countries in the world. Being the most abundant fossil fuel in India till date, it continues to be one of the most important sources for meeting the domestic energy needs and accounts for 55\% of the country's total energy supplies. The development of core infrastructure sectors like power, steel, and cement are dependent on coal. Coal has been recognized as the most important source of energy for electricity generation in India. About $75 \%$ of the coal in India is consumed in the power sector. In addition, other industries like steel, cement, fertilizers, chemicals, paper and thousands of medium and small-scale industries are also dependent on coal for their process and energy requirements. In the transport sector, though direct consumption of coal by the Railways is almost negligible on account of phasing out of steam locomotives, the energy requirement for electric traction is still dependent on coal converted into electric power.

The demand for coal has risen by about 8.0 per cent per annum during the Eleventh Plan and may rise by about the same magnitude during the Twelfth Plan. Coal output expanded at about 7.0 per cent per year in the fiveyear period of 2004-05 to 2009-10, with especially strong growth in both 2008-09 and 2009-10. However, in 2010- 
11 coal production remained stagnant. Domestic coal production was originally targeted to reach $680 \mathrm{mt}$ in the Eleventh Plan. This was scaled down to $630 \mathrm{mt}$ in the Mid Term Appraisal and it is now expected to be only 554 $\mathrm{mt}$. Of the 208 captive coal blocks allotted with 49 billion tonnes of reserves and a production potential of $657 \mathrm{mt}$ per annum, the estimated annual production by the end of the Eleventh Plan is only $37 \mathrm{mt} .3 .38$ Given the strong growth in thermal generation projected in the Twelfth Plan, the aggregate demand for coal at the end of the Twelfth Plan is likely to be between 900 and 1,000 million tonnes depending upon the pace of implementation of power capacity. As against the projected demand of 900-1,000 million metric tonnes ( $\mathrm{mt}$ ) by the end of the Twelfth Plan, the domestic output is unlikely to exceed $750 \mathrm{mt}$ leaving more than $200 \mathrm{mt}$ shortfall to be met from imports. Even this assumes that domestic output will be able to increase by over $200 \mathrm{mt}$ from current levels (Planning commission). A historical summary of India's energy consumption and production of coal and lignite are shown in the table 1.

\begin{tabular}{|l|l|l|l|l|l|l|}
\hline \multicolumn{8}{|c|}{ Table 1 Consumption and Production of Energy from 1970-71 to 2013-14 } \\
\hline $\begin{array}{l}\text { Energy consumption } \\
\begin{array}{l}\text { \& production (in } \\
\text { '000 tonnes). }\end{array}\end{array}$ & $\begin{array}{l}1970-71 \text { to } \\
1979-80\end{array}$ & $\begin{array}{l}1980-81 \text { to } \\
1989-90\end{array}$ & $\begin{array}{l}1990-91 \text { to } \\
1999-2000\end{array}$ & $\begin{array}{l}2000-01 \text { to } \\
2009-10\end{array}$ & $\begin{array}{l}2010-11 \text { to } \\
2013-14\end{array}$ & $\begin{array}{l}1970-71 \\
2013-14\end{array}$ \\
\hline $\begin{array}{l}\text { Coal and lignite } \\
\text { (consumption) }\end{array}$ & 92165 & 161228.8 & 292757.3 & 445314.2 & 595152.5 & 279437.8 \\
\hline $\begin{array}{l}\text { Coal \& lignite } \\
\text { (production) }\end{array}$ & 1946.1 & 3271.3 & 4986.3 & 7111.7 & 9545.2775 & 4803.070682 \\
\hline
\end{tabular}

From the above table it is observed that the average consumption of coal and lignite was 92165 tonnes ('000) during the period of 1970-71 to 1979-80 and that of production was 1946.1 tonnes ('000). In 1990-91 to 19992000 it was 292757.3 and 4986.3 tonnes ('000) respectively which increased to 595152.5 and 9545.2775 tonnes ('000) in 2010-11 to 2013-14. Total energy consumption and production of coal and lignite was 279437.8 and 4803.07068 tonnes ('000). It is also observed that the consumption of coal and lignite is increasing year by year more than production.

Inspite of various policy initiatives to diversify the fuel mix but considering the limited reserve potentiality of petroleum \& natural gas, eco-conservation restriction on hydel project and geo-political perception of nuclear power, it is becoming increasingly evident that coal will continue to occupy centre-stage of India's energy scenario. Indian coal offers a fuel source to domestic energy market for the next century \& beyond. Based on estimates, the consumption of coal is projected to rise by nearly 40 percent over the next five years and almost to double by 2020 .

\subsection{Oil and Natural Gas}

According to the planning commission, by the year 2020, oil and natural gas will meet $44 \%$ of India's energy requirement compared to $50 \%$ by coal. Nuclear and hydel energy would form $2.5 \%$ and $3.5 \%$ respectively. Natural gas may form $14 \%$ of our energy needs in 2020 compared to $8.6 \%$ today. The importance of oil in India can be derived from the fact that oil accounts for $36 \%$ of the primary energy mix in India. If we consider natural gas, this percentage increases to $44 \%$. However, the proportion of natural gas is approximately one third of the world average, once again indicating the potential for rapid growth.

The latest estimates indicate that India has around $0.4 \%$ of the world's proven reserves of crude oil. The production of crude oil in India has increased from 6.82 MT in 1970/ 71 to 33.38 MT in 2003/ 04 (MoPNG). The production of natural gas increased from 1.4 BCM (billion cubic metres) to $31.96 \mathrm{BCM}$ during the same period. The quantity of crude oil imported increased from 11.66 MT during 1970/ 71 to 81 MT by 2003/ 04 .

Besides, imports of other petroleum products increased from 1 MT to 7.3 MT during the same period. The exports of petroleum products went up from around 0.5 MT during 1970/ 71 to 14 MT by 2003/ 04. The refining capacity, as on 1 April 2004, was 125.97 MTPA (million tonnes per annum). The production of petroleum products increased from 5.7 MT during 1970/ 71 to 110 MT in 2003/ 04.

India's consumption of natural gas has risen faster than any other fuel in the recent years. Natural gas demand has been growing at the rate of about $6.5 \%$ during the last 10 years. Industries such as power generation, fertilizer, and petrochemical production are shifting towards natural gas. India's natural gas consumption has been met entirely through domestic production in the past. However, in the last 4-5 years, there has been a huge unmet demand of natural gas in India, mainly required for the core sectors of the economy.

To bridge this gap, apart from encouraging domestic production, the import of LNG (liquefied natural gas) is being considered as one of the possible solutions for India's expected gas shortages. Several LNG terminals have been planned in the country. Two LNG terminals have already been commissioned: (1) Petronet LNG Terminal of 5 MTPA (million tonnes per annum) at Dahej, and (2) LNG import terminal at Hazira. In addition, an inprinciple agreement has been reached with Iran for import of 5 MTPA of LNG. 
Table 2 Consumption and Production of Oil \& Natural Gas from 1970-71 to 2013-14

\begin{tabular}{|c|l|l|l|l|l|l|}
\hline \multicolumn{7}{|c|}{ Table 2 Consumption and Production of Oil \& Natural Gas from 1970-71 to 2013-14 } \\
\hline Sources of energy & $\begin{array}{l}1970-71 \text { to } \\
1979-80\end{array}$ & $\begin{array}{l}1980-81 \text { to } \\
1989-90\end{array}$ & $\begin{array}{l}1990-91 \text { to } \\
1999-2000\end{array}$ & $\begin{array}{l}2000-01 \text { to } \\
2009-10\end{array}$ & $\begin{array}{l}2010-11 \text { to } \\
2013-14\end{array}$ & $\begin{array}{l}1970-71 \text { to } \\
2013-14\end{array}$ \\
\hline $\begin{array}{l}\text { Consumption of Crude } \\
\text { oil (in'000 tonnes). }\end{array}$ & 22342.5 & 39706.5 & 60878.6 & 135853.5 & 210705 & 77968.89 \\
\hline $\begin{array}{l}\text { Consumption of natural } \\
\text { gas (in million cubic } \\
\text { metres). }\end{array}$ & 1121.2 & 5465.8 & 18461.1 & 29603.2 & 39002.5 & 15966.43 \\
\hline $\begin{array}{l}\text { Production of crude } \\
\text { oil(in'000 tonnes) }\end{array}$ & 368 & 1088.2 & 1324 & 1391.6 & 1585.25 & 1092.25 \\
\hline $\begin{array}{l}\text { Production of natural } \\
\text { gas(in million cubic } \\
\text { metres) }\end{array}$ & 82.9 & 323.6 & 850.1 & 1275 & 1275 & 729.34 \\
\hline
\end{tabular}

In this case before 90 s the consumption of crude oil was 39706.5('000) tones which is growing faster in 201011 to $2013-14$ i.e. 210705 ' 000 tones. As compare to consumption the production of crude oil is low. There is rapid increase in production of oil from 197071 to2009-10 i.e 368'000 tones to 1391.6 '000 tones. Total average oil production during the period of $1970-2014$ is $1092.25^{\prime} 000$ tones which is lower than that of consumption. The consumption of natural gas has increased from 1121.2 million cubic metres in 1970-71-1979-80 to 18461.1 million cubic metres in 1999-2000. In 2010-11 to 2013-14 the average consumption is 39002.5 million cubic metres and that of production is 1275 million cubic metres. Similarly the consumption of natural gas is higher than the production.

\subsection{Electricity}

India is presently sixth-greatest electricity generating country and accounts for about $4 \%$ of the world's total annual electricity generation. India is also currently ranked sixth in annual Electricity consumption, accounting for about $3.5 \%$ of the world's total annual electricity consumption. The utility electricity sector in India had an installed capacity of $303 \mathrm{GW}$ as of 30 June 2016. During the year 2014-15, the per capita electricity generation in India was $1010 \mathrm{KWh}$ with total electricity consumption of $746 \mathrm{KWh}$ per capita electricity consumption. It is lower compared to many countries despite cheaper electricity tariff in India. By the end of 2015, despite poor hydro electricity generation, India has become power surplus country with huge power generation capacity idling for want of electricity demand. Overall, India's need for power is growing at a prodigious rate; annual electricity generation and consumption in India have increased by about $64 \%$ in the past decade, and its projected rate of increase for electricity consumption is one of the highest in the world. Electricity consumption in India has more than doubled in the last decade. The primary energy supply in the country is coal-dominant, with the power sector accounting for about 40 percent of primary energy and 70 percent of coal consumption (CMIE, 2000). The Indian power sector is characterized by large demand-supply gap. Faced with unreliable power supply, many industries have invested in on-site power generation that now accounts for more than 10 percent of total capacity (CMIE, 2000). Five regional grids operate in India, with regional grids connecting state transmission networks within a region. The average production and consumption of electricity during the period of 1970-71 to 2013-14 has given below in the table-3.

\begin{tabular}{|c|l|l|l|l|l|l|}
\hline \multicolumn{6}{|c|}{ Table 3 Consumption and Production of Electricity (in GWh) from 1970-71 to 2013-14 } \\
\hline Sources of energy & $\begin{array}{l}1970-71 \\
\text { to 1979- } \\
80\end{array}$ & $\begin{array}{l}1980-81 \text { to } \\
1989-90\end{array}$ & $\begin{array}{l}1990-91 \text { to } \\
1999-2000\end{array}$ & $\begin{array}{l}2000-01 \text { to } \\
2009-10\end{array}$ & $\begin{array}{l}2010-11 \text { to } \\
2013-14\end{array}$ & $\begin{array}{l}1970-71 \\
2013-14\end{array}$ \\
\hline $\begin{array}{l}\text { Production to } \\
\text { electricity (in GWh) }\end{array}$ & 129.3 & 202.2 & 298.4 & 1270.7 & 1696.0525 & 586.1411364 \\
\hline $\begin{array}{l}\text { Consumption of } \\
\text { electricity(GWh) }\end{array}$ & 59428 & 122489.2 & 259337.3 & 428740.1 & 810708.5 & 271426.8 \\
\hline
\end{tabular}

From the above table it is cleared that the average production is highest in 2010-11 to 2013-14 i.e 1696.0525 $\mathrm{GWh}$ and that of consumption is $810708.5 \mathrm{GWh}$. In this case also the electricity consumption is higher than electricity production. There is increasing consumption and production of electricity year by year but production is slower than consumption.

\section{Growth rate of energy consumption and production:-}

To find out the growth rate of primary conventional energy consumption and production, we calculate the compound growth rate of energy such as coal, lignite, natural gas, crude oil and electricity which can be described in the following manner. 


\subsection{Growth rate of energy consumption:-}

The growth rate of energy consumption of coal and lignite was 4.71\% in 1970-71 to 1979-80 which was increased to $6.90 \%$ during the period of $1980-81$ to $1989-90$. Further the growth rate was falling to $4.60 \%$ in $1990-91$ to 1999 2000 which was slidly increased to $4.90 \%$ during the period of $2000-01$ to $2009-10$. In the next period the growth rate was further falling to $2.99 \%$ (2010-11 to 2013-14). There is happening of erratic growth rate of energy consumption of coal and lignite. The growth rate of crude oil was 4.35\% in 1970-71 to $1979-80$ which was increased to $7.83 \%$ in next ten years. But the growth rate was declining during the period of 1990-91 to 1999-2000. Further the growth rate of oil increased to $5.96 \%$ in next decade. Over all the total growth rate of crude oil consumption is $5.99 \%$ (1970-2014) which was more than that of coal \& lignite. In case of natural gas the growth rate of consumption was $12.77 \%$ in $1970-71$ to $1979-80$ which was increased to $23.82 \%$ during the period of 1980 81 to $1989-90$. But the growth rate was declining to $7.33 \%$ in $2000-01$ to $2009-10$. After this period the growth rate was continuously declining and reaches to $-9.81 \%$ in $2010-11$ to $2013-14$ which was negative in nature. The total growth rate of natural gas from $1970-71$ to $2013-14$ is $10.58 \%$ which was greater than that of coal\& lignite and crude oil. On the other hand there is fluctuation in growth rate of electricity consumption in different periods. The highest growth rate was happened in 2010-11 to 2013-14 i.e. $12.05 \%$. The total growth rate of electricity consumption during the whole period was $6.86 \%$. The above analysis has been shown in the table 4 .

\begin{tabular}{|l|l|l|l|l|l|l|}
\hline \multicolumn{6}{|c|}{ Table 4 Growth rate of energy consumption during the period of 1970-71 to 2013-14. } \\
\hline $\begin{array}{l}\text { Sources of } \\
\text { energy }\end{array}$ & $\begin{array}{l}1970-71 \text { to } \\
1979-80\end{array}$ & $\begin{array}{l}1980-81 \text { to } \\
1989-90\end{array}$ & $\begin{array}{l}1990-1991 \\
1999-00\end{array}$ & $\begin{array}{l}2000-01 \text { to } \\
2009-10\end{array}$ & $\begin{array}{l}2010-2011 \\
2013-14\end{array}$ & $\begin{array}{l}\text { Total (1970- } \\
2014)\end{array}$ \\
\hline $\begin{array}{l}\text { Coal and } \\
\text { lignite }\end{array}$ & 4.71 & 6.90 & 4.60 & 4.90 & 2.99 & 5.32 \\
\hline Crude oil & 4.35 & 7.83 & 4.99 & 5.96 & 4.46 & 5.99 \\
\hline Natural gas & 12.77 & 23.82 & 7.33 & 1.15 & -9.81 & 10.58 \\
\hline electricity & 7.14 & 8.75 & 5.79 & 7.15 & 12.05 & 6.86 \\
\hline
\end{tabular}

From the above table and analysis it is cleared that the growth rate of natural gas was more than the rest part of energy consumption in India.

\section{Growth rate of energy production}

The growth rate under coal and lignite production in $1970-71$ to $1979-80$ was $4.64 \%$ and it increases to $6.03 \%$ in $1980-81$ to $1989-90$. Further the growth rate was declining to $3.31 \%$ in next year's and it again increases to $5.27 \%$ in 2000-01 to 2009-10. Then it declines to $2.38 \%$ in the years $2010-11$ to $2013-14$. There is no faster increase in growth rate of coal \& lignite production. In the case of crude oil growth rate was highest in 1980-81 to 1989-90 i.e. $11.33 \%$.further the growth rate was continuously falling to $0.05 \%$ during the period of $2000-01$ to $2009-10$. After all the growth rate was nil in the period of 2010-1 to 2013-14. Hence it shows that the overall growth rate was very slow and it is less than that of coal \& lignite. There is no such difference between them. In case of natural gas the growth rate was $9.01 \%$ in $1970-71$ to $1979-80$ and it increases to $21.57 \%$ in $1980-81$ to $1989-90$ which was highest during the study period. The lowest growth rate was occurred in $2010-11$ to $2013-14(-12.38 \%)$ respectively. It means that there is no growth rate during this period. The overall growth rate was more than that of oil and coal \& lignite says $9.04 \%$. Electricity growth rate was $7.07 \%$ in $1970-71$ to $1979-80$ and it declined to $2.15 \%$ in next 20 years. It further increases at a higher rate to $32.45 \%$ in $2000-01$ to $2009-10$ and again declines to $-47.62 \%$. During the whole period the maximum growth rate was occurred in case of natural gas and minimum was crude oil production. It can be shown in the table-3.e below.

Table 5 Compound growth rate of production of primary conventional energy during the period of 1970-71 to 2013-14.

\begin{tabular}{|c|c|c|c|c|c|c|}
\hline $\begin{array}{l}\text { Sources of } \\
\text { energy }\end{array}$ & $\begin{array}{ll}1970-71 & \text { to } \\
1979-80 & \end{array}$ & $\begin{array}{ll}1980-81 & \text { to } \\
1989-90 & \end{array}$ & $\begin{array}{l}1990-91 \text { to } \\
1999-2000\end{array}$ & $\begin{array}{l}2000-01 \\
2009-2010\end{array}$ & $\begin{array}{ll}2010-11 & \text { to } \\
2013-14 & \end{array}$ & $\begin{array}{l}\text { Total(1970- } \\
2014)\end{array}$ \\
\hline Coal \& lignite & 4.64 & 6.03 & 3.31 & 5.27 & 2.38 & 4.38 \\
\hline Crude oil & 6.77 & 11.33 & 1.24 & 0.50 & -0.00 & 3.95 \\
\hline Natural gas & 9.01 & 21.57 & 5.98 & 3.16 & -12.38 & 9.04 \\
\hline Electricity & 7.07 & 2.76 & 2.15 & 32.45 & -47.62 & 5.73 \\
\hline
\end{tabular}

Hence the growth rate was highest in case of electricity i.e. $32.45 \%$ during the period of 2000-01 to 2009-10 than that of production of primary conventional energy.

\section{Mann-Kendall trend test and Sen's Slope Analysis:-}

After the growth rate of energy consumption and production in this study we have used non-parametric (MannKendall, Sen's slope estimator) methods to detect the trends in coal\& lignite, natural gas, crude oil and electricity which are discussed below. 


\subsection{Energy consumption}

In Mann-Kendall trend test positive values of $Z$ indicate increasing trends while negative $Z$ values show decreasing trend. Here the $\mathrm{Z}$ values of coal \& lignite, crude oil, natural gas and electricity consumption are positive and also $\mathrm{p}$ values are zero, so the trends of primary conventional energy consumption of coal, lignite, oil, natural gas and electricity are increasing from 1970-71 to 2013-14. Mann-Kendall test is complemented with Sen's Slope estimation to determine the magnitude of the trend. The slope of coal and lignite was 12884.2063 ' 000 tonnes per annum. The slope of crude oil was $3696.4843^{\prime} 000$ tonnes which is less than that of coal\& lignite. The slope of coal\& lignite is highly significant, so it is not best fit for estimation because it does not represent properly in a series. Similarly, in case of natural gas and electricity the slopes are 981.21 million cubic metres per annum and $12758.12 \mathrm{GWh}$ respectively. Her also the slopes are highly significant. It can be better shown in the following table 6

\begin{tabular}{|l|l|l|l|l|}
\hline \multicolumn{4}{|c|}{ Table 6 Primary conventional Energy Consumption analysis(1970-71 to 2013-14) } \\
\hline Sources of energy & Sen'slope & P & Z & SE \\
\hline Coal \& lignite(in`000 tones) & 12884.2063 & 0.0000 & 9.4669 & 1360.9670 \\
\hline Crude oil(in'000 tones) & 3696.4843 & 0.0000 & 9.4467 & 391.2981 \\
\hline Natural gas(million cubic metres) & 981.2100 & 0.0000 & 8.8601 & 110.7449 \\
\hline Electricity(in GWh) & 12758.1290 & 0.0000 & 9.4503 & 1350.0273 \\
\hline
\end{tabular}

\subsection{Energy production}

Here the $\mathrm{Z}$ values of coal \& lignite, crude oil, natural gas and electricity consumption are positive and also $\mathrm{p}$ values are zero, so the trends of primary conventional energy production of coal, lignite, oil, natural gas and electricity are increasing from 1970-71 to 2013-14. Mann-Kendall test is complemented with Sen's Slope estimation to determine the magnitude of the trend. The slope of coal and lignite was 177.54 ' 000 tonnes per annum. The slope of crude oil was $26.31^{\prime} 000$ tonnes which is less than that of coal\& lignite. The slope of coal\& lignite is significant, so it is best fit for estimation because it represents properly in a series. Similarly, in case of natural gas and electricity the slopes are 41.15 million cubic metres per annum and $9.33 \mathrm{GWh}$ respectively. Her also the slopes are significant and it is the best for estimation. It can be better shown in the following table 7

\begin{tabular}{|l|l|l|l|l|}
\hline \multicolumn{5}{|c|}{ Table 7 Primary conventional energy production analysis (1970-71 to 2013-14) } \\
\hline Sources of energy & Sen'slope & P & Z & SE \\
\hline Coal \& lignite & 177.5417 & 0.0000 & 9.3860 & 18.9155 \\
\hline Crude oil & 26.3137 & 0.0000 & 6.8574 & 3.8373 \\
\hline Natural gas & 41.1598 & 0.0000 & 9.1332 & 4.5066 \\
\hline Electricity & 9.3333 & 0.0000 & 8.6376 & 1.0805 \\
\hline
\end{tabular}

From the above analysis it shows that the trend of both energy consumption and production of coal\& lignite, natural gas, crude oil and electricity are positive.

\section{Conclusion}

The current energy system runs primarily on different sources of energy i.e. coal \& lignite, petroleum, hydro and natural gas. Massive amounts of energy are consumed from petroleum sources as well, however in non-electrical uses such as transportation. Unfortunately, all these energy sources have drawbacks. Coal \& petroleum are fossil fuels and therefore inherently limited in quantity. These fuels are also highly polluting and cannot form the basis for a completely sustainable society. The other major source, hydroelectric power, has also come under fire from various groups due to adverse effects it imposes upon local aquatic life.

All have their drawbacks, it is important to consider the potential for changing to more sustainable energy sources. There are significant renewable resources available throughout the country while solar energy is by and large limited in terms of its potential (at least near potential). Several areas have excellent wind or geothermal resources. At this time we conclude that renewable energy resources do have the potential to provide a significant amount of energy in the country. Renewable energy can contribute to education as well, by providing electricity to schools, improving attendance, retaining teachers, and powering educational media. Renewable energy for cooking and heating can reduce the time that children, especially girls, spend out of school collecting fuel. In addition, the displacement of traditional fuels reduces the health problems from indoor air pollution produced by burning those fuels. Renewable energy can also contribute to improved health by providing energy to refrigerate medicine, sterilize medical equipment, and incinerate medical waste. And it can provide power for supplying the fresh water and sewer services needed to reduce the burden of infectious disease. Most renewable energy sources require a significant upfront investment, as has been the case for most of the conventional energy sources that dominate today's energy system. This means that in the early years of deployment, renewable energy options are typically more expensive than the conventional alternative. Government intervention to level the playing field is therefore needed to start the development process. Experience shows that as the scale of use increases, costs decline 
significantly in the early years.

\section{Reference}

Pokharel, S.H. (2006) “An Econometrics Analysis of Energy Consumption in Nepal”, Energy Policy, pp. 1-12. Kendall, M. G. (1975). Rank Correlation Methods (4 ${ }^{\text {th }}$ ed.). Griffin, London. $202 \mathrm{p}$

Mann, H. B. (1945). Nonparametric tests against trend. Econometrica, Journal of the Econometric Society, 13, $245-259$.

Sen, P. K. (1968). Estimates of the regression coefficient based on Kendall's tau. Journal of the American Statistical Association, 63, 1379-1389. 